\title{
Modelling the flood vulnerability of deltaic Kuching City, Malaysia
}

\author{
Darrien Yau Seng Mah • Frederik Josep Putuhena • Sai Hin Lai
}

Received: 6 March 2009/Accepted: 16 January 2011

(C) Springer Science+Business Media B.V. 2011

\begin{abstract}
The main objective of this writing is to present a practical way to envisage the flood vulnerability in deltaic region, particularly on the concern of sea level rise. Kuching city of Malaysia is established on banks of Sarawak River, $30 \mathrm{~km}$ from the sea. Therefore, it is subjected to fluvial and tidal floods. Kuching Bay experiences the highest King Tides in Southeast Asia region. These tide magnitudes could be a glimpse of future sea level rise. By means of modelling these tides, it provides an understanding and preparation for the impacts of sea level rise on the flood mitigation infrastructures and the city itself. The modelling efforts had created an illustration that a $10 \%$ rise in tide levels would result in increase of flooding areas up to $6 \%$ relative to existing tide levels.
\end{abstract}

Keywords Flood $\cdot$ Infoworks RS $\cdot$ Kuching $\cdot$ River $\cdot$ Sea level rise $\cdot$ King Tides

\section{Background}

Kuching flat is drained by the Sarawak and Samarahan Rivers as major channels, intertwined by multiple smaller channels. In this river delta, the capital Kuching city of Sarawak State is established beside Sarawak River about $30 \mathrm{~km}$ from the estuary (see Fig. 1). The average elevation of the city is $+5 \mathrm{~m} \mathrm{AD}$, and the mean sea level is at $+4.5 \mathrm{~m} \mathrm{AD}$. Its

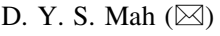

River Engineering and Urban Drainage Research Centre (REDAC), Universiti Sains Malaysia, 14300 Nibong Tebal, Penang, Malaysia

e-mail: darrien.mah@gmail.com

F. J. Putuhena

Department of Civil Engineering, Faculty of Engineering, Universiti Malaysia Sarawak, 94300 Kota Samarahan, Sarawak, Malaysia

e-mail: fjputuhena@feng.unimas.my

S. H. Lai

Department of Civil Engineering, Faculty of Engineering, Universiti Malaya, 50603 Kuala Lumpur, Malaysia

e-mail: laish@um.edu.my
} 